\title{
WOOD ANATOMY OF THE VANGUERIEAE (IXOROIDEAE- RUBIACEAE), WITH SPECIAL EMPHASIS ON SOME GEOFRUTICES
}

\author{
by
}

\author{
Frederic Lens ${ }^{1}$, Steven Jansen ${ }^{1}$, Elmar Robbrecht ${ }^{2}$ \& Erik Smets ${ }^{1}$
}

\begin{abstract}
SUMMARY
The Vanguerieae is a tribe consisting of about 500 species ordered in 27 genera. Although this tribe is mainly represented in Africa and Madagascar, Vanguerieae also occur in tropical Asia, Australia, and the isles of the Pacific Ocean. This study gives a detailed wood anatomical description of 34 species of 15 genera based on LM and SEM observations. The secondary xylem is homogeneous throughout the tribe and fits well into the Ixoroideae s.l. on the basis of fibre-tracheids and diffuse to diffuse-in-aggregates axial parenchyma. The Vanguerieae include numerous geofrutices that are characterised by massive woody branched or unbranched underground parts and slightly ramified unbranched aboveground twigs. The underground structures of geofrutices are not homologous; a central pith is found in three species (Fadogia schmitzii, Pygmaeothamnus zeyheri and Tapiphyllum cinerascens var. laetum), while Fadogiella stigmatoloba shows central primary xylem which is characteristic of roots. Comparison of underground versus aboveground wood shows anatomical differences in vessel diameter and in the quantity of parenchyma and fibres.
\end{abstract}

Key words: Vanguerieae, Rubiaceae, systematic wood anatomy, geofrutex.

\section{INTRODUCTION}

The Vanguerieae (Ixoroideae-Rubiaceae) is a large tribe consisting of about 500 species and 27 genera. Tropical Africa is the centre of diversity (about $80 \%$ of the species are found in Africa and Madagascar), although the tribe is also present in tropical Asia, Australia, and the isles of the Pacific Ocean (Bridson 1987). Most representa tives are shrubs, but some are lianas or large trees. The Vanguerieae are morphologically homogeneous and they are characterised by a number of common features which clearly define the tribe from other Rubiaceae, such as the axillary paired inflorescences, a valvate aestivation, secondary pollen presentation, one pendulous ovule per locule, pyrenes with an apical germination slit, and soft oily endosperm with very large embryos (Robbrecht 1988). In the most recent global system of the Rubiaceae (Robbrecht 1988, 1994), the Vanguerieae were placed in the subfamily Antirheoideae,

1) Institute of Botany and Microbiology, Laboratory of Plant Systematics, K.U.Leuven, Kardinaal Mercierlaan 92, B-3001 Heverlee, Belgium.

2) National Botanic Garden of Belgium, Domein van Bouchout, B-1860 Meise, Belgium. 
i.e. were considered to be related to Alberteae, Guettardeae, Retiniphylleae and Knoxieae. This view corresponds to the classical systems of the Rubiaceae; Schumann (1891) for instance united these tribes in a supertribe "Guettardinae". Recent molecular analyses have proved that the Antirheoideae are polyphyletic and that Vanguerieae and the closely related Alberteae show affinities to the Ixoroideae (Bremer et al. 1995; Andreasen \& Bremer 1996; Andreasen et al. 1999; Rova 1999).

The great morphological homogeneity within the Vanguerieae goes hand in hand with major difficulties in the delimitation of the genera. This problem was discussed by Verdcourt $(1958,1987: 123)$ who emphasised "the poorness of characters used for generic delimitation". According to him, the naturalness of the Vanguerieae should result in reducing the amount of genera. Robyns (1928) was the first taxonomist who revised the tribe, however without treating Canthium which is the largest genus. After a revision of the East African representatives of Canthium by Bullock (1932), it was Igersheim (1989) and especially Bridson (1992, and literature cited therein) who contributed to the delimitation of this large genus. The latter author divided Canthium s.l. into several genera on the basis of morphological characters, a decision which contradicted the ideas of Verdcourt. The division of the large Canthium complex was also supported by Tilney et al. (1988) who studied anatomical characters of young stems.

The wood anatomy of the Vanguerieae is poorly known (e.g., Janssonius 1926; Pearson \& Brown 1932; Chang 1951; Desch 1954; Lebacq \& Deschamps 1967; Lomibao 1975; Normand \& Paquis 1976; Gill \& Onuja 1984; Purkayastha 1982; Sosef et al. 1998). These authors described only one or two genera, especially Canthium and Psydrax sensu Bridson (1992). Koek-Noorman and Hogeweg (1974) give a brief summary of the tribe, based however on 12 species of Canthium, Keetia, Meyna, Psydrax, Rytigynia, and Vangueria only.

The Vanguerieae, especially the genera Pygmaeothamnus, Pachystigma, Fadogia, Fadogiella, Lagynias and Tapiphyllum, are characterised by a relatively large amount of geofrutices or geoxylic shrubs. These are plants with woody massive underground parts and slightly ramified, shortly living aboveground twigs. The geofrutescent habit is mainly confined to (sub)tropical savanna regions of Africa, mainly in the Zambesian region where many geofrutices are endemic in the Kalahari desert. A preliminary review of the distribution, ecology and evolution of these "underground forests of Africa" was presented by White (1976). He concluded that this growth form has not evolved in reaction to fire or frost, but as a response to unfavourable edaphic conditions. Because there is, as far as we know, no literature available about underground parts of geofrutices, the Vanguerieae are an interesting group in which to study the wood anatomy of these structures.

The present paper gives a detailed wood anatomical description of selected species of the Vanguerieae, including four geoxylic representatives.

\section{MATERIAL AND METHODS}

Wood samples of 34 species of 15 genera were obtained from the wood collection of Tervuren (Tw), Leiden (L), and the herbarium of the National Botanic Garden of Belgium (BR). The material studied is listed below with reference to the origin, collector, 
and the diameter of the wood sample (in mm). 'Large' indicates mature wood samples although the exact diameter could not be traced. The abbreviation ' $U W$ ' is used for the four investigated underground wood samples of geofrutices.

Canthium ciliatum (D. Dietr.) Kuntze, South Africa, Farm Rustfontein, H. J. Schlieben 7351 (BR), 5 mm. - Canthium inerme (L.f.) Kuntze, Zimbabwe, A.C. Chase 5351 (BR), 7 mm. - Canthium lactescens Hiern, Rwanda, Kagera, J. Lebrun 9685 (BR), 10 mm. - Canthium mundianum Cham. \& Schltdl., South Africa, Forest Research Institute 1641 (Tw 26109), large. - Canthium parasiebenlistii Bridson, Tanzania, Iringa region, Mufundi, Penny Pennis Farm, R.K. Brummitt et al. 18165 (BR), 8 mm. - Canthium setiflorum Hiern, Ethiopia, Sidamo, J. Ash 2444 (BR), 7 mm. - Canthium simile Merr. \& Chun, China, Guangdong, Forest Research Institute 266 (Tw 42123), large. - Cuviera longiflora Hiern, Congo(-Kinshasa), Yangambi, J. Louis 1255 (Tw 33127), 19 mm. - Cuviera nigrescens Wernham, Congo(-Kinshasa), R. Deschamps 640 (Tw 8502), large. - Fadogia schmitzii Verdc., Congo(-Kinshasa), Kolwezi, A. Schmitz 2958 (BR), 5 mm, UW 13 mm. - Fadogiella stigmatoloba (K. Schum.) Robyns, Congo(-Kinshasa), F. Malaisse (BR), 5 mm, UW 12 mm. - Keetia cornelia (Cham. \& Schltdl.) Bridson, Senegal, Casamance, J. Dewolf s.n. (Tw 51615), 8 mm. - Keetia cf. gueinzii (Sond.) Bridson, Congo(-Kinshasa), J. Louis 1198 (Tw 33115), 20 mm. - Keetia cf. hispida (Benth.) Bridson, Congo(-Kinshasa), J. Louis 1852 (Tw 33301), 22 mm. - Lagynias pallidiflora Bullock, Tanzania, H.J. Schlieben 2135 (BR), 5 mm. - Meyna pubescens (Kurz) Robyns, Thailand, Chiang Mai, Doi Sutep-Pui N.P., J.F. Maxwell 90-527 (L), 11 mm. - Meyna spinosa Roxb. ex Link, India, Maharashtra, Birla Institute of Scientific Research 55140 (Tw 44939), large. - Pachystigma pygmaeum (Schltr.) Robyns, Congo(-Kinshasa), Katanga, S. Lisowiski 9669 (BR), 5 mm. - Pachystigma solitariifolia Verdc., Tanzania, Dodoma district, Ruffo 1164 (BR), 6 mm. - Psydrax sp., South India, Pomudi, C.E. Ridsdale 503 (L), large. - Psydrax horizontalis (Schumach. \& Thonn.) Bridson, Ivory Coast, C. Geerling and J. Bokdam 1035 (BR), 8 mm. - Psydrax subcordata (DC.) Bridson var. subcordata, Congo(-Kinshasa), De Briey 134 (Tw 68), 10 mm. - Pygmaeothamnus zeyheri (Sond.) Robyns, South Africa, C. Puff 2631 (BR), 5 mm, UW 9 mm. - Pyrostria sp., Congo(-Kinshasa), J. Louis 2215 (Tw 33410), 16 mm. - Pyrostria affinis (Robyns) Bridson, Rwanda, G. Bouxin 784 (Tw 35034), 19 mm. - Pyrostria madagascariensis Lecomte, Madagascar, Thouvenot 4053 (Tw 30782), large. - Rytigynia bagshawei (S. Moore) Robyns var. lebrunii (Robyns) Verdcourt, Rwanda, G. Bouxin 784 (Tw 24176), large. - Rytigynia umbellata (Hiern) Robyns, Congo(-Kinshasa), Luiswishi, F. Malaisse 9601 (Tw 35154), large. - Rytigynia verruculosa (K. Krause) Robyns, Congo(-Kinshasa), J. Louis 5598 (BR), 10 mm. - Tapiphyllum cinerascens (Welw. ex Hiern) Robyns var. laetum (Robyns) Verdc., Congo (-Kinshasa), Kumanua, F. Malaisse 9658 (BR), 5 mm, UW 35 mm. - Vangueria cf. infausta Burch., Angola, Cunenc, Roçadas, R. Deschamps et al. 1253 (Tw 28309), 26 mm. - Vangueria infausta Burch., Congo(-Kinshasa), Katanga, F. Malaisse 9373 (Tw 31826), 22 mm. - Vangueriopsis sp., Congo(-Kinshasa), J. Louis 3379 (Tw 35404), large. - Vangueriopsis longiflora (Hiern) Robyns, Congo(-Kinshasa), Katanga, F. Malaisse 9122 (Tw 31257), $20 \mathrm{~mm}$. 


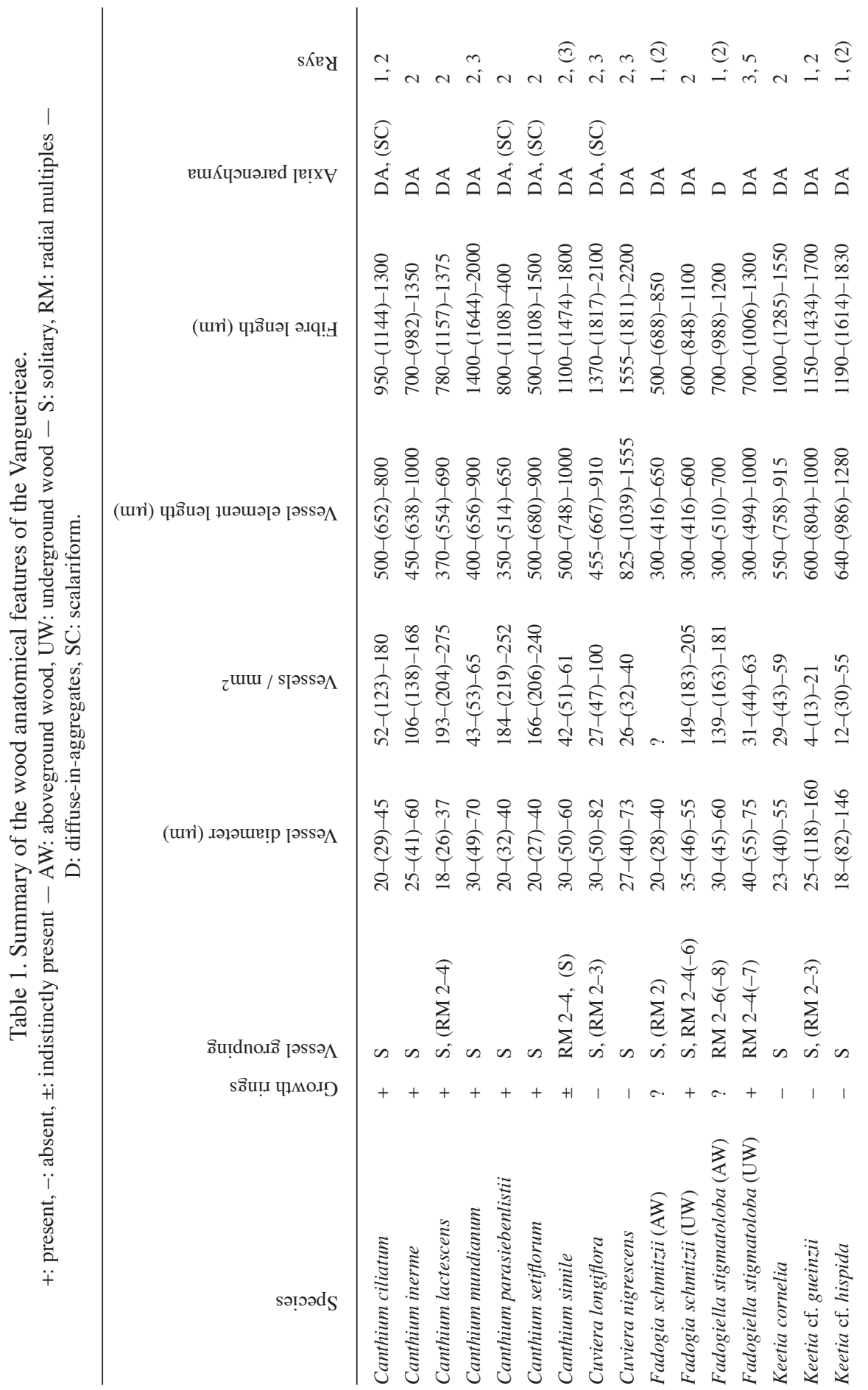




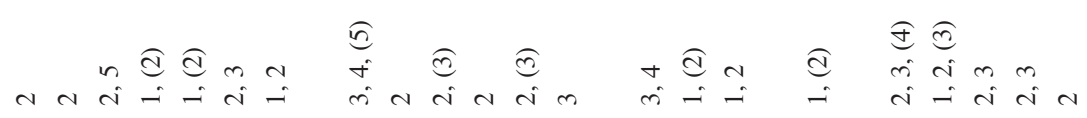

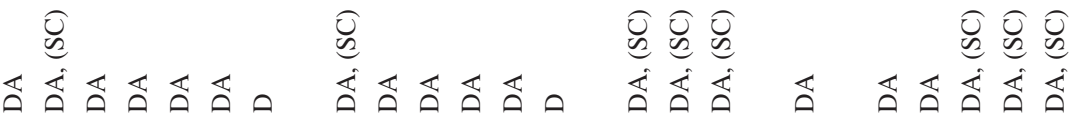

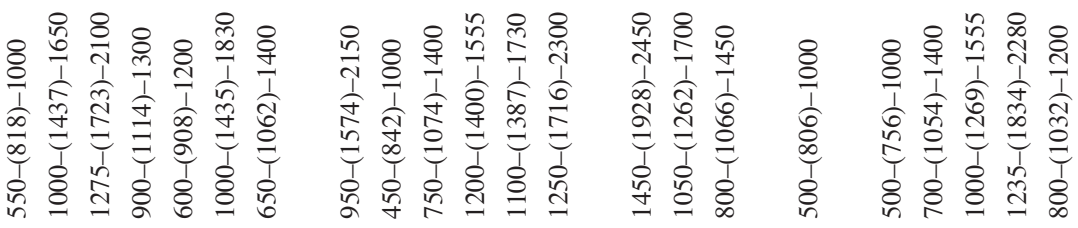

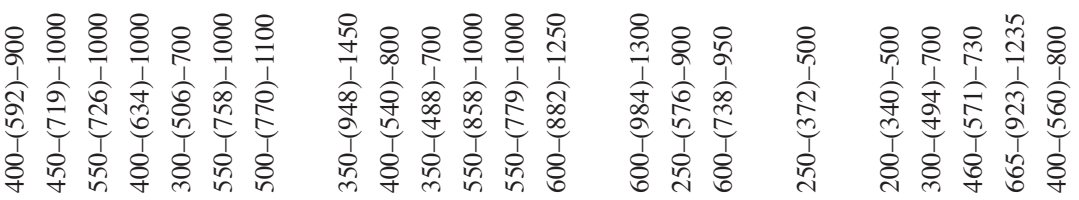

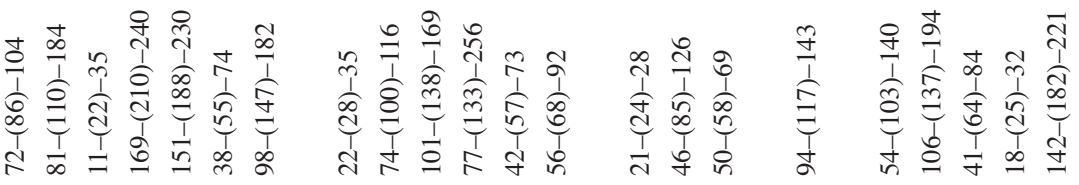

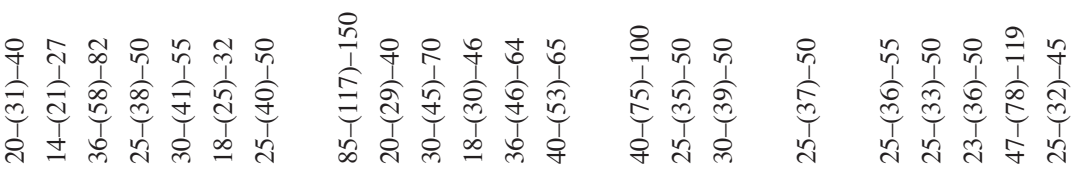

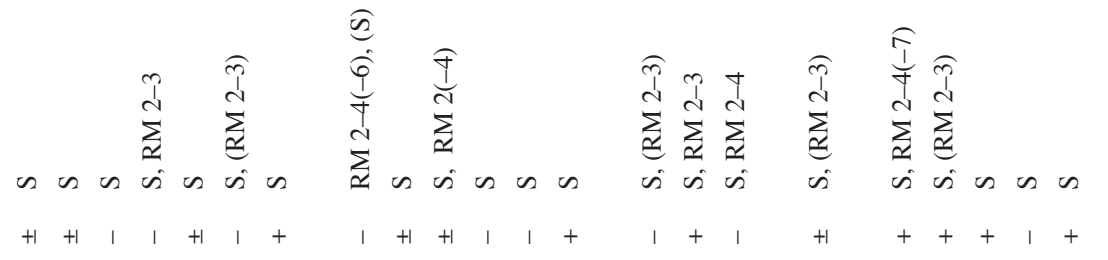

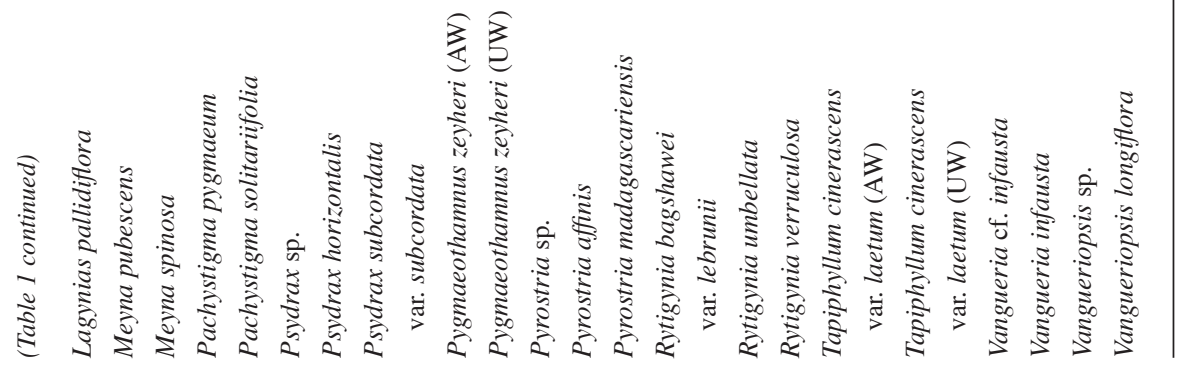


The preparation of wood for light microscopy (LM) and scanning electron microscopy (SEM) is according to Jansen et al. (1998). Macerations were prepared according to Franklin (1945). The wood anatomical terms are used in accordance with the IAWA Committee (1989). Mean length of vessel elements and fibres and mean vessel diameter were based on 25 measurements; vessels in ten fields of $1 \times 1 \mathrm{~mm}$ were counted for vessel frequency. For the definition of fibre-tracheids and libriform fibres, we follow Koek-Noorman (1969).

\section{RESULTS}

The measurements for the different vessel and fibre features are always mean values. A summary of the wood anatomical results is listed in Table 1.

\section{Wood anatomy of aboveground stems}

Growth rings usually distinct in e.g. Lagynias and Vangueria; sometimes indistinct in Canthium simile (Fig. $1 \& 4$ ) or absent in the two species investigated of Cuviera.

Wood diffuse-porous. Vessels mainly solitary in Canthium (Fig. 3), Keetia (Fig. 4) and Pyrostria; sometimes in short radial multiples (2-3) in e.g. Canthium simile (Fig. 1 \& 2). Vessel outline slightly angular to irregular (Fig. 1-6). Perforation plates always simple and oval to circular. Intervessel pits alternate, minute to small, vestured (Fig. 14, 15 \& 16), and sometimes elongated in e.g. Vangueriopsis sp. (Fig. 14) and Psydrax subcordata var. subcordata. Vessel-ray pits with distinct borders and similar to intervessel pits in size and shape throughout the ray cell. Smallest tangential diameter of vessel lumina $21 \mu \mathrm{m}$ (Meyna pubescens), largest diameter $118 \mu \mathrm{m}$ in Keetia cf. gueinzii, on average rather small $(48 \mu \mathrm{m})$. Lowest vessel density 13 in Keetia cf. gueinzii, highest value 206 in Canthium setiflorum, mean vessel density 87. Vessel element length on average $740 \mu \mathrm{m}$, extreme values of $494 \mu \mathrm{m}$ in Vangueria cf. infausta and $1039 \mu \mathrm{m}$ in Cuviera nigrescens. Tyloses present in Keetia cf. gueinzii.

Fibres always with distinctly bordered pits $(>3 \mu \mathrm{m})$ common in both radial and tangential walls, sometimes vestured. Fibres always non-septate and thin- to thickwalled; fibres very thick-walled in Pyrostria madagascariensis. Fibre length on average $1398 \mu \mathrm{m}$, shortest fibres in Canthium inerme (982 $\mu \mathrm{m})$, longest fibres in Pyrostria madagascariensis $(1928 \mu \mathrm{m})$.

Apotracheal parenchyma diffuse (Fig. 6) to diffuse-in-aggregates (Fig. 3, 4 \& 5); in some species of Canthium (Fig. 1 \& 2), Cuviera, Rytigynia, Meyna, Psydrax and Vangueriopsis also a tendency to scalariform parenchyma. Mostly 5-8 cells per parenchyma strand. Pith flecks present in e.g. Keetia (Fig. 4).

Rays usually 1- or 2-seriate (Fig. 10); 3-seriate in Rytigynia bagswahei var. lebrunii (Fig. 9) and in Pyrostria madagascariensis (Fig. 11); up to 4- or 5-seriate in Meyna spinosa and Psydrax subcordata var. subcordata. Rays always heterocellular, heterogeneous type I (Kribs 1935); body ray cells procumbent, with $>4$ rows of upright and/or square marginal cells (Fig. 13). Perforated ray cells in e.g. Rytigynia, Canthium and Vangueria (Fig. 17); vessel-ray perforations always simple and circular to oval (Fig. 17); in Fadogiella stigmatoloba, tangential multiples of 2-5 perforated ray cells 
present at the end of the long uniseriate part of a ray (Fig. 12). Rays $>12$ per mm and often connected with each other (Fig. $9 \&$ 10). Ray height often $>1 \mathrm{~mm}$.

Crystals absent in the wood. Druses regularly present in the central pith in Canthium, Vangueria cf. infausta (Fig. 19) and Keetia cornelia.
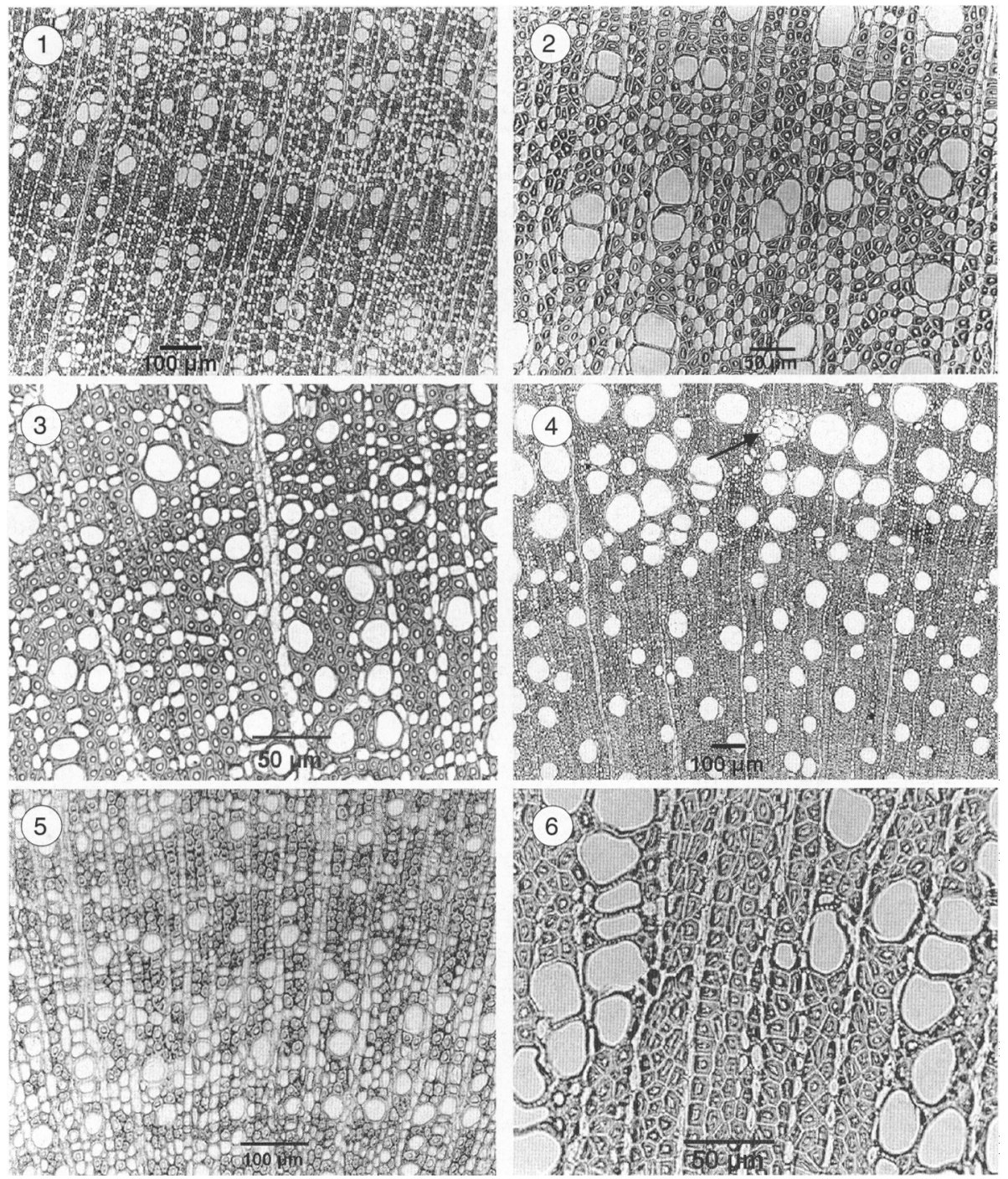

Fig. 1-6. Transverse sections. - 1: Canthium simile, vessels in radial multiples of 2-4. 2: Canthium simile, tendency to scalariform axial parenchyma. - 3: Canthium parasiebenlistii, vessels solitary and diffuse-in-aggregates axial parenchyma. - 4: Keetia $\mathrm{cf}$. gueinzii, wide and small solitary vessels, pith fleck present (arrow). - 5: Pygmaeothamnus zeyheri, vessels solitary or in small radial multiples, axial parenchyma diffuse-in-aggregates. -6 : Aboveground part of Fadogiella stigmatoloba, vessels in radial multiples of 2-6. 

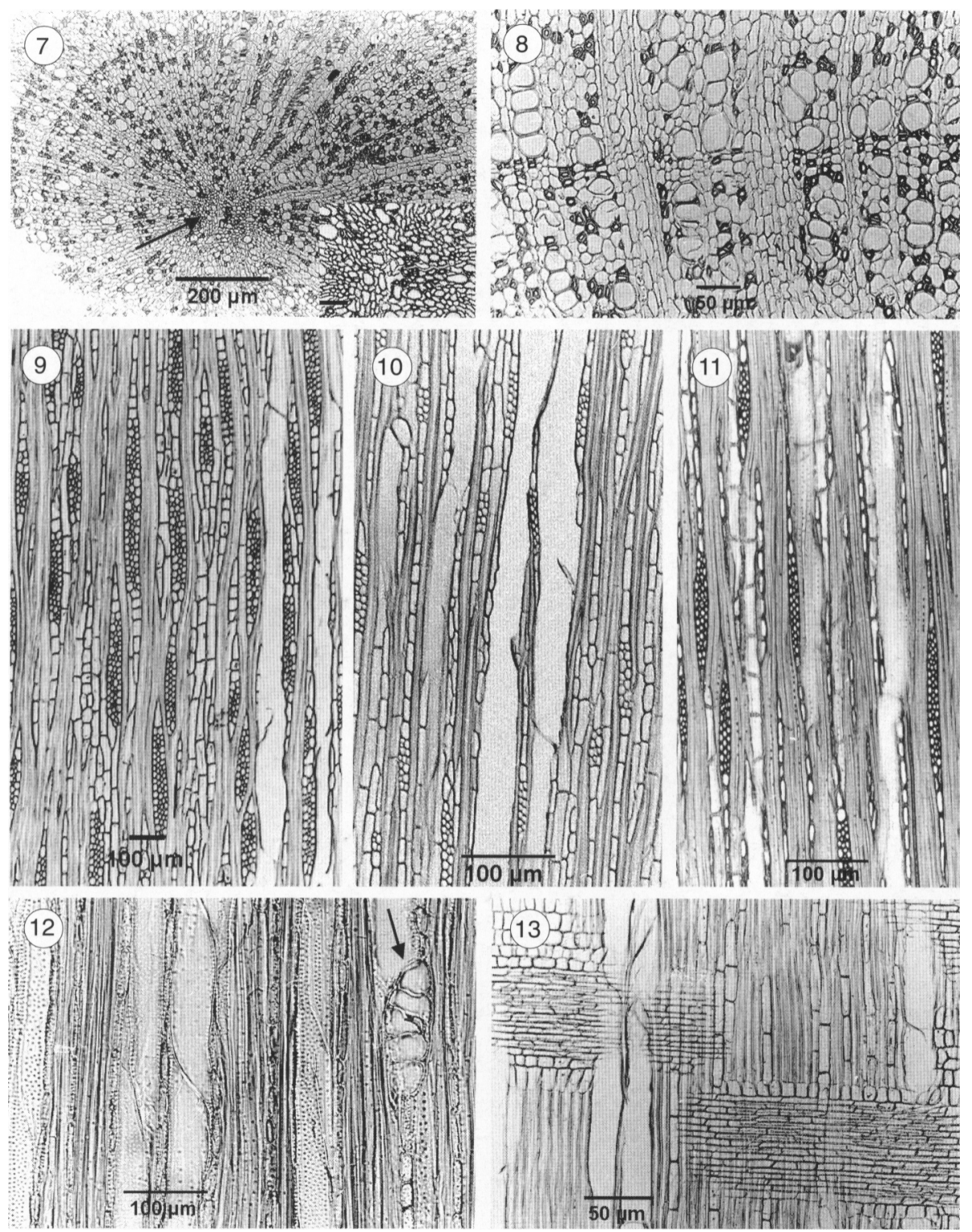

Fig. $7 \&$ 8. Transverse section of the underground part of Fadogiella stigmatoloba. - 7: Primary xylem in the centre (arrow), detail of central primary xylem in the right corner (scale bar: $25 \mu \mathrm{m}$ ). -8 : Vessels in radial multiples of $2-4$, axial parenchyma abundant, fibres uncommon, wide rays. - Fig. 9-12. Tangential sections. - 9: Rytigynia bagshawei var. lebrunii, 3- or 4-seriate rays, sometimes connected. - 10: Canthium simile: 1- or 2-seriate rays, frequently connected. - 11: Pyrostria madagascariensis, 3-seriate rays. - 12: Aboveground part of Fadogiella stigmatoloba, vessel-ray multiples of 5 perforated ray cells (arrow). - Fig. 13. Rytigynia bagshawei var. lebrunii, radial section showing procumbent body ray cells and upright/square marginal ray cells. 

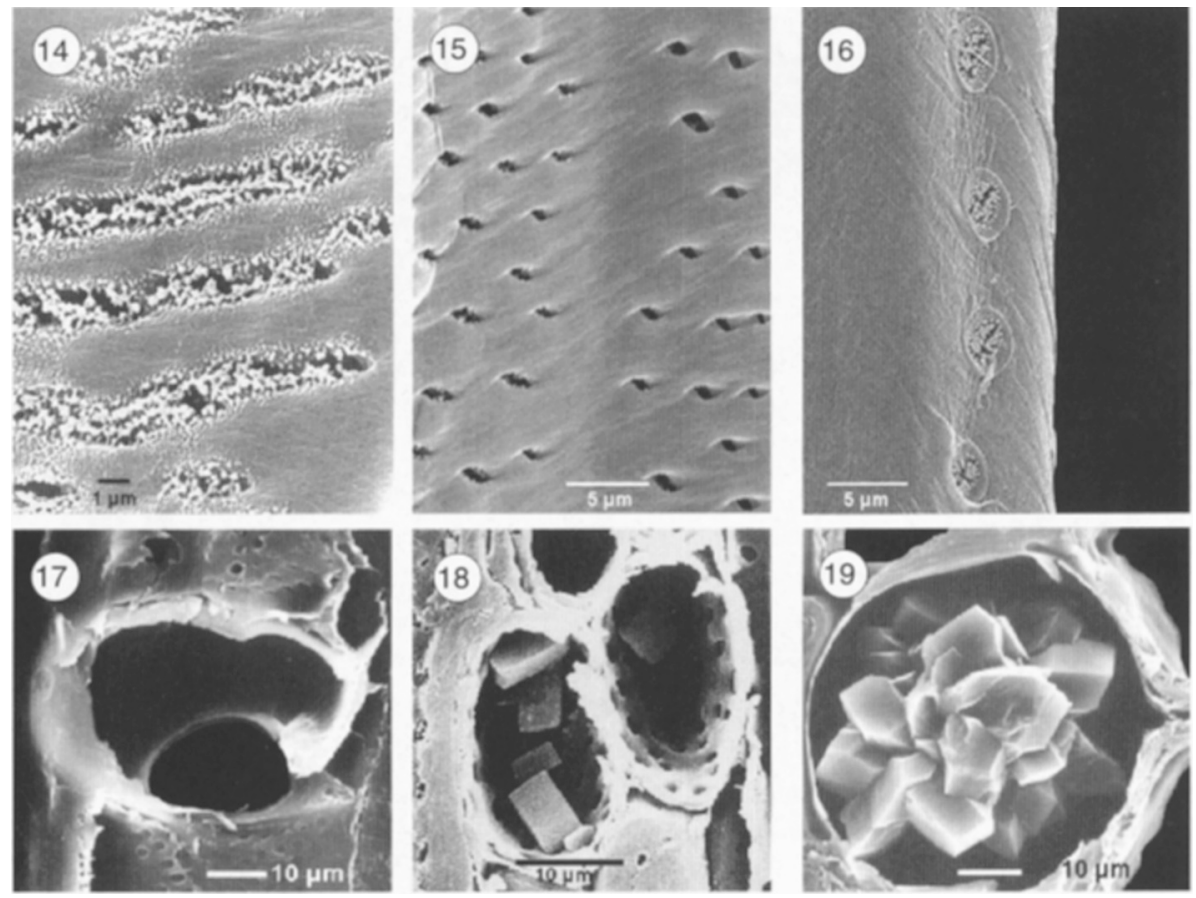

Fig. 14-16. Vestured vessel pits. - 14: Vangueriopsis longiflora, vestured pits viewed from the inner side of a vessel. - 15: Aboveground part of Fadogiella stigmatoloba, vessel pits viewed from the lumen side, vestures scarcely present near the inner pit aperture. - 16: Lagynias pallidiflora, vestured pits viewed from the outer surface of a vessel element, vestures fill up the pit chamber. - Fig. 17. Vangueria infausta, simple vessel-ray perforation. - Fig. 18. Underground part of Fadogia schmitzii, prismatic crystals in ray cells. - Fig. 19. Vangueria infausta, druse in a central pith parenchyma cell.

\section{Underground parts of geofrutices}

Several wood anatomical differences between underground and aboveground parts of the same species are found (except for Pygmaeothamnus zeyheri). For quantitative features, see Table 1.

In Fadogia schmitzii, growth rings are distinct in the underground wood, although absent in its aboveground wood; vessel pits are elongated throughout the length of some vessel members in underground wood, but non-elongated vessel pits in aboveground stems; many small prismatic, elongated, and navicular crystals present in body and marginal ray cells of underground wood (Fig. 18), although no crystals in aboveground stems. In Tapiphyllum cinerascens var. laetum, up to seven vessels occur in radial multiples of underground wood, but multiples are only up to three cells in aboveground wood. In Fadogiella stigmatoloba, presence of primary xylem in the underground part (Fig. 7), but a central pith in its aboveground part; distinct growth rings in the underground part (Fig. $7 \&$ 8), but absent in its aboveground wood; vessels usually in radial multiples, but more distinct in aboveground wood (Fig. 6); pa- 
renchyma tissue richly present in underground wood (Fig. 8), although diffuse in the aboveground part (Fig. 6); rays wide (mostly 3-, 4- or 5-seriate or sometimes up to 8 -seriate) in underground wood (Fig. $7 \& 8$ ), while narrow (uni- or biseriate) in aboveground wood (Fig. 6).

\section{DISCUSSION}

\section{Systematic implications}

As mentioned in the introduction, the Vanguerieae show a high degree of homogeneity. This is also demonstrated by our observations, which are in agreement with previous qualitative and quantitative wood features of Rubiaceae (Koek-Noorman 1969; Koek-Noorman \& Hogeweg 1974; Jansen et al. 1997a, b, 1999). Several wood anatomical features of the tribe are characteristic of Ixoroideae s.1., namely solitary vessels and a low percentage of vessels in small radial multiples, fibre-tracheids, and axial parenchyma diffuse to diffuse-in-aggregates (Koek-Noorman 1972; Jansen et al. 1997a, 1999, unpublished observations).

A transition between solitary vessels and small radial multiples of vessel elements occurs (e.g. in Canthium), which was also reported by Koek-Noorman and Hogeweg (1974). As in nearly all Rubiaceae, vessel-vessel and vessel-ray perforations in the study group are simple and circular to oval (Koek-Noorman 1969; Jansen et al. 1997a, b, 1999). Rudall (1982), however, described an unusual type of vessel-ray perforation in Canthium barbatum (= now Cyclophyllum barbatum - Vanguerieae). Vestures are always present in the Vanguerieae in association with vessel pits; they even appear to characterise all Gentianales (Jansen \& Smets 2000). In Vanguerieae, the mean tangential diameter of vessel lumina is generally narrow, but wider in lianas (all examined species of Keetia and Psydrax subg. Psydrax). Wood of the lianescent Keetia cornelia, however, has narrow vessels probably because of the thin wood sample studied.

The most common type of axial parenchyma in the Vanguerieae is diffuse to diffuse-in-aggregates. In some species of Canthium and Vangueriopsis there is even a tendency to scalariform parenchyma. This was also observed by Koek-Noorman and Hogeweg (1974); moreover, they observed bands of axial parenchyma in Canthium confertum.

Tangential multiples of perforated ray cells occur in the aboveground twig of Fadogiella stigmatoloba. It is known that multiple perforated ray cells have little taxonomic value because the character is not constant even in a single species (Chalk \& Chattaway 1932).

Although crystals in the wood of the Vanguerieae are absent, several genera (e.g. Canthium) show druses in their central pith. This occurrence cannot be generalised, because the wood samples investigated did not always show a central pith. Moreover, druses are missing in Pyrostria, Vangueriopsis and Meyna. The lack of crystals in the wood of the Vanguerieae, however, distinguishes the tribe from some other tribes of the Ixoroideae s.l. The Coffeeae show abundant prismatic crystals in their ray cells (Jansen et al. 1997a), and prismatic crystals in ray cells are also present in some gen- 
era of the Aulacocalyceae, Octotropideae, and Gardenieae (S. Jansen: unpublished observations). Moreover, styloids or elongate crystals and crystals in chambered axial parenchyma cells are found in respectively the Ixoreae and the Pavetteae s. s. (Jansen et al. 1999).

\section{Comparison between underground and aboveground parts}

Our results of the underground parts of geofrutescent shrubs reveal that they are not so homogeneous as we may suspect. One may clearly define two different types of underground structures. The first type, observed in Fadogia schmitzii, Pygmaeothamnus zeyheri and Tapiphyllum cinerascens var. laetum, is characterised by the presence of a central pith. These structures may be called underground stems. A feature specific of the second type of underground parts is the primary xylem situated in the centre. This root structure is only observed in Fadogiella stigmatoloba.

The underground stems of geofrutices are very similar to their aboveground stems, despite some quantitative differences. In Fadogia schmitzii and Pygmaeothamnus zeyheri, for instance, the tangential diameter of the vessels is smaller (mean value of the two species about $30 \mu \mathrm{m}$ ) and the fibre length is shorter (mean value of the two species $765 \mu \mathrm{m}$ ) in the aboveground stems than in their underground stems (respectively $45 \mu \mathrm{m}$ and $961 \mu \mathrm{m}$ ). On the other hand, the vessel diameter (about $40 \mu \mathrm{m}$ ) and the fibre length (about $750 \mu \mathrm{m}$ and $800 \mu \mathrm{m}$ ) of the underground and aboveground stem of Tapiphyllum cinerascens var. laetum are similar. Furthermore, distinct growth rings occur in the underground wood of Fadogia (and Fadogiella), but they are lacking in the aboveground wood of the same specimens. An obvious explanation for this is the smaller diameter of the aboveground wood samples because aboveground stems of geofrutices may die back towards the base as a result of savanna fires which occur frequently. Moreover, aboveground stems of some geofrutices become moribund after a relatively short period of time, even when no destructive ecological factors occur (White 1976). The underground parts, however, usually stay intact during the whole life time of the plant so that growth rings may be formed. Another difference between underground and aboveground stems is that numerous small prismatic and elongated crystals occur in underground ray cells of Fadogia schmitzii, while crystals are absent in the aboveground wood.

When one compares the quantitative characters of underground stems of geofrutices with aboveground stems of non-geofrutices, mainly quantitative differences are found. The vessel density is higher in the three underground stems (on average $141 / \mathrm{mm}^{2}$ ) compared to aboveground stems of non-geofrutices (on average $87 / \mathrm{mm}^{2}$ ). Also, the length of the vessel elements $(740 \mu \mathrm{m})$ and the fibres $(1398 \mu \mathrm{m})$ in non-geofrutescent stems is generally longer than vessel elements and fibres in underground stems of geofrutices (resp. $415 \mu \mathrm{m}-893 \mu \mathrm{m}$ ). Besides these quantitative differences, radial multiples of 2-7 vessels are more common in the underground stems.

It is generally known that there are several differences between the secondary xylem of roots and stems. Wider vessel elements with a lower vessel density characteristically occur in roots, and they generally have more parenchyma tissue and less fibres compared to stems (e.g. Cutler 1976; Metcalfe \& Chalk 1983). This is confirmed 
by our observations on the two types of underground wood. The vessel diameter of rootwood in Fadogia stigmatoloba $(55 \mu \mathrm{m})$ is wider than the mean underground vessel diameter of other geofrutices investigated (on average $42 \mu \mathrm{m}$ ). The vessel density in the underground rootwood of Fadogia stigmatoloba is much lower $\left(44 / \mathrm{mm}^{2}\right)$ than that of the underground wood in the other geofrutices (on average $141 / \mathrm{mm}^{2}$ ). It is also very obvious that the amount of parenchyma tissue (axial parenchyma as well as ray parenchyma) is much higher in the underground wood of Fadogiella stigmatoloba than in the underground stemwood of other geofrutescent species.

Apparently, stem characteristics as well as root features can be found in underground parts.

\section{ACKNOWLEDGEMENTS}

The curator of the xylarium of Tervuren (Dr. Hans Beeckman) and the director of the herbarium of Leiden (Prof. Pieter Baas) are acknowledged for the loan of herbarium material and for the permission to execute anatomical studies. We also thank Marcel Verhaegen for making some SEM photographs. This research was supported by grants from the Research Council of the K.U. Leuven (OT/97/23).

\section{REFERENCES}

Andreasen, K., B.G. Baldwin \& B. Bremer. 1999. Phylogenetic utility of the nuclear rDNA ITS region in subfamily Ixoroideae (Rubiaceae): comparisons with cpDNA rbcL sequence data. Pl. Syst. Evol. 217: 119-135.

Andreasen, K. \& B. Bremer. 1996. Phylogeny of the subfamily Ixoroideae (Rubiaceae). Opera Bot. Belg. 7: 119-138.

Bremer, B., K. Andreasen \& D. Olsson. 1995. Subfamilial and tribal relationships in the Rubiaceae based on rbcL sequence data. Ann. Missouri Bot. Gard. 82: 383-397.

Bridson, D.M. 1987. Studies in African Rubiaceae-Vanguerieae: a new circumscription of Pyrostria and a new subgenus, Canthium subgen. Bullockia. Kew Bull. 42: 611-639.

Bridson, D.M. 1992. The genus Canthium (Rubiaceae-Vanguerieae) in tropical Africa. Kew Bull. 47: 353-401.

Bullock, A. A. 1932. Canthium in British East Africa. Bull. Misc. Inf. Kew 8: 353-389.

Chalk, L. \& M. M. Chattaway. 1932. Perforated ray cells. Proc. Roy. Soc. Lond. B 113: 82-92.

Chang, Y.-P. 1951. Anatomy of wood and bark in the Rubiaceae. Doctoral dissertation. University of Michigan.

Cutler, D.F. 1976. Variations in root wood anatomy. In: P. Baas, A.J. Bolton \& D.M. Catling (eds.), Wood structure in biological and technological research. Leiden Bot. Series 3: 143-156.

Desch, H.E. 1954. Malayan Forest Records Nr. 15. Manual of Malayan timbers. Vol. 2. Malayan Publishing House Ltd., Singapore.

Franklin, G.L. 1945. Preparations of thin sections of synthetic resins and wood-resin composites, and a new macerating method for wood. Nature 155: 51.

Gill, L.S. \& J.E. Onuja. 1984. A comparative study of the tracheary elements of some commercial hardwoods of Nigeria. Feddes Repert. 95: 645-655.

IAWA Committee. 1989. IAWA list of microscopic features for hardwood identification. IAWA Bull. n.s. 10: 219-332.

Igersheim, A. 1989. Beiträge zur Klärung der Gattungsabgrenzungsprobleme innerhalb der Rubiaceae-Vanguerieae. Unpublished doctoral dissertation, Botanical Institute, University of Vienna.

Jansen, S., P. De Block, H. Beeckman \& E. Smets. 1999. Systematic wood anatomy of the Pavetteae (Rubiaceae-Ixoroideae). Syst. Geogr. Pl. 68: 113-133. 
Jansen, S., P. Kitin, H. De Pauw, M. Idris, H. Beeckman \& E. Smets. 1998. Preparation of wood specimens for transmitted light microscopy and scanning electron microscopy. Belg. J. Bot. 131: 41-49.

Jansen, S., E. Robbrecht, H. Beeckman \& E. Smets. 1997a. Comparative wood anatomy of African Coffeeae (Rubiaceae-Ixoroideae). Belg. J. Bot. 130: 47-58.

Jansen, S., E. Robbrecht, H. Beeckman \& E. Smets. 1997b. Wood anatomy of the predominantly African representatives of the tribe Psychotrieae (Rubiaceae-Rubioideae). IAWA J. 18: 169196.

Jansen, S. \& E. Smets. 2000. Morphology, distribution and systematic importance of vestures in the Gentianales. In: B. Nordenstam, G. El-Ghazaly \& M. Kassas, Plant systematics of the $21^{\text {st }}$ century: 277-296. Portland Press, London.

Janssonius, H.H. 1926. In: J.W. Moll \& H.H. Janssonius (eds.), Mikrographie des Holzes der auf Java vorkommenden Baumarten. IV. E. J. Brill Publ., Leiden.

Koek-Noorman, J. 1969. A contribution to the wood anatomy of South American (chiefly Suriname) Rubiaceae. I. Acta Bot. Neerl. 18: 108-123.

Koek-Noorman, J. 1972. The wood anatomy of Gardenieae, Ixoreae and Mussaendeae (Rubiaceae). Acta Bot. Neerl. 21: 301-320.

Koek-Noorman, J. \& P. Hogeweg. 1974. The wood anatomy of the Vanguerieae, Cinchoneae, Condamineeae and Rondeletieae (Rubiaceae). Acta Bot. Neerl. 23: 627-653.

Kribs, D.A. 1935. Salient lines of structural specialization in the wood rays of dicotyledons. Bot. Gaz. 96: 547-557.

Lebacq, L. \& R. Deschamps. 1967. Contribution à un inventaire des forêts du Nord Kasai. Ann. Mus. Roy. Afr. Centr. Tervuren: 454-457, 461.

Lomibao, B.A. 1975. Wood anatomy of 9 Rubiaceae species. II. Forpride Digest 4: 70-71.

Metcalfe, C.R. \& L. Chalk. 1983. Anatomy of the dicotyledons. Ed. 2. Vol. 2. Clarendon Press, Oxford.

Normand, D. \& J. Paquis. 1976. Manuel d'identification des bois commerciaux. Vol. 2. Afrique Guinéo-Congolaise. Centre Tech. For. Trop. Nogent-sur-Marne.

Pearson, R.S. \& H.P. Brown. 1932. Commercial timbers of India. Vol. 2. Their distribution, supplies, anatomical structure, physical and mechanical properties and uses. Calcutta.

Purkayastha, S.K. 1982. Indian woods, their identification, properties and uses. Vol. 4. Myrtaceae to Symplocaceae.

Robbrecht, E. 1988. Tropical Woody Rubiaceae. Characteristic features and progressions. Contributions to a new sufamilial classification. Opera Bot. Belg. 1.

Robbrecht, E. 1994 ('1993'). Supplement to the 1988 outline of the classification of the Rubiaceae. Index to genera. Opera Bot. Belg. 6: 173-196.

Robyns, W. 1928. Tentamen monographiae Vanguerieae generumque affinium. Bull. Jard. Bot. Etat Brux. 11: 1-359.

Rova, J. 1999. The Condamineeae-Rondeletieae-Sipaneeae-complex. Unpublished doctoral dissertation. University of Göteborg.

Rudall, P. 1982. An unusual perforation plate in Canthium barbatum Seem. (Rubiaceae). IAWA Bull. n.s. 3: 127-129.

Schumann, K. 1891. Rubiaceae. In: A. Engler \& K. Prantl (eds.), Die natürlichen Pflanzenfamilien 4. W. Engelmann, Leipzig.

Sosef, M.S.M., L.T. Hong \& S. Prawirohatmodjo (eds.). 1998. Plant resources of South-East Asia. Nr. 5. Timber trees: lesser known timbers, Backhuys Publishers, Leiden.

Tilney, P.M., A.E. van Wyk \& P.D.F. Kok. 1988. The taxonomic significance of anatomical characters of the stem in the southern African species of Canthium s.l. (Rubiaceae). S. Afr. J. Bot. 54: 585-595.

Verdcourt, B. 1958. Remarks on the classification of the Rubiaceae. Bull. Jard. Bot. Etat Brux. 28: 209-281.

Verdcourt, B. 1987. Notes on African Rubiaceae-Vanguerieae. Kew Bull. 42: 123-199.

White, F. 1976. The underground forests of Africa: a preliminary review. Garden's Bull. 39: $57-71$. 